\title{
OPTIMASI MAGNESIUM ALUMINIUM SILIKAT SEBAGAI PENGENTAL DALAM SEDIAAN DEODORAN
}

\author{
Ridha Arizal ${ }^{1}$, Mamay Maslahat ${ }^{2}$ dan Indah Amalya ${ }^{3}$ \\ 1. 2) Program Studi Kimia FMIPA, Universitas Nusa Bangsa Bogor \\ JI. KH Soleh Iskandar KM 4 Cimanggu Tanah Sareal Bogor 16166 \\ 2Laboratorium Research and Development, PT Paragon Technology and Innovation, \\ Jalan Raya IV No. 4 Blok AG, kawasan Industri Jatake Tangerang, Banten \\ Telp. (0251)8340217, Fax : (0251)7535605 \\ ${ }^{1}$ Email : ridhayasmin@gmail.com
}

\begin{abstract}
Optimation of Magnesium Aluminium Silicate as a Thickener in Deodorant Formulation

Deodorant is an oil-in-water emulsion system $(\alpha / w)$ which has a certain viscosity which serves fo rechuce body odor as a resalt of chrmical chamges carsed by bacterita attrittex Viscasify of deodorant is influenced by emulsifier which is a compound luavig surface activities of air - liquad and liqaid - Itquid east in the system. The addition of thickening agent is to increase the viscosity of a formalation. Thickener used is Magnesium Aluminum Sticate (MLAS). Reseanch methods wiciuded the lotion preparation of deodorant malang process usting $\mathrm{MAS}$ thitckener concentratton of $0.5 \%, 1.0 \%, 1.5 \%$ and $2.0 \%$ and a deodarant without thickener was used as a control. Each treatment was repeated three times. Purameters include the test of organoleptic meanurements (shape, color, and odar), pH. Brootfield viscovify, the stabifity of the emalsion, the soral microbial furting. and testung paruils. The results showed that the cptimal concentration of MAS as a thickener in the mampfacare of deodorant was at a concentration of $0.5 \%$. The deodorant at a MAS concentration of $0.5 \%$ had lotion chanacteristic of a milky white color, specific odor, $\mathrm{pH} 49$, vitcosity of $1294 \mathrm{cp}$, total mierobes wert negative. All panameters were in accordance with company standards. However, at a concentration of $0.5 \%$ MAS generates an instable emuditon.
\end{abstract}

Key Words : deodorant, emulsifier, Magnesium Atuminżum Silicate

\section{ABSTRAK}

Deodoran mesupakan sistem emulsi minyak 'dalum air (m/a) yang memilika kekentalan lertentu yang berfungsi untuk mergurangi bau badin akibat perubahan kimia oleh bakteri. Kekentalan deodoran dipergamhi olch emulsifier yaitu suatu senyawa yang menpunyai aktifitas permukaan antara udara - cairan dan cairan cainun yang terdupat dulaun sautu sistem. Penumbahan pengental metupukant cara untuk meninglautkun kekentalan statu sodiaan, pengental yang diguakan yaitu Magnesium Aluminium Silikat (MAS) Metode penelitian meliputi proses pembuatan lotion deodoran menggunakan pengental MAS dengan konsentrasi $0,5 \%, 1,0 \%, 1,5 \%$, dan $2,0 \%$ sata deodoran tarna pengental sebagai kontrol. Masing-masing periakuan dilakukan pergulangan sebanyak tiga kali. Parameter perneriksaan yang dilakukan meliputi, pengukuran organoleptik (bentrk, wama, dan aroma), nilai pH, kekentalan metode Brookfield, stabilitas emulsi, uji total mikroba, dan uji panel. Hasil penditian menujjukkan k:cnsentrasi MAS yang optimal sebagai pengental dalam pentbuatan dzodornin adalah konsentrasi $0,5 \%$. Deodoran pada konsentrasi MAS 0,5\% ini mempunyai karakteristik bontuk lotion, wama putih susu, bau thas, pH 4,9, viskositas $1294 \mathrm{cp}$, total mikroba memunjukban hasil negatif. Semua panmeter tersebut sesuai dengan standar perusahuan. Akan tetapi pada konsentrasi MAS $0,5 \%$ menghasilkan emulsi yang tidak stabil.

Kafa Kunci : deodaran, amulsifier, Magnesium Aluminam Silikat

\section{PENDAHULUAN}

Kulit merupakan bagian organ tethas pada manusia yang berfungsi untuk melindungi organ tubuh dari sinar ultraviolet, mengatur suhu tubuh dan sebagai tempat saraf bekerja. Kulit terdiri atas tiga lapisan utama yaitu epidermis, dermis dan hipodermis dimana masing masing bagian lapisan kulit tersebut mempunyai fungsi tersendiri. 
Lapisan epidermis merupakan lapisan pelindung bagian luar, yang berfungsi menjaga kulit dari kekeringan. polusi, sinar matahari dan bakteri. Lapisan epidermis ini terdiri atas stratum kornetum, stratum husidum, stratum granulostum. stratum spinosum dan stratum basalis. Lapisan kulit kedua setelah lapisan epidermis adalah lapisan dermis. Lapisan dermis merupakan jaringan penghubung yang menyediakan sistem pendukung dan nutrisi bagi lapisan epidermis, Lapisan ini terdiri atas pembuluh darah, saraf, kelenjar minyak (sebasea) dan kelenjar keringat. Kelenjar keringat terdiri atas kelenjar ekrin dan kelenjar apokrin. Kelenjar ekrin jumlahnya sckitar dua juta kelenjar yang berfungsi untuk mengontrol suhu tubuh dan mengandung sodium klorida sebagai hasil sekresi kelenjar keringat. Kelenjar apokrin terdapat dibawah lengan dan berhubungan dengan organ seks. Lapisan yang ketiga adalah lapisan hipodermis atau subkutan yaitu lapisan jaringan tebal di bawah dermis yang menjaga bentuk tubuh dan suhu tubuh. Lapisan ini merupakan kelanjutan dermis, terdiri atas jaringan ikat longgar bcrisi sel-sel lemak didalamnya (Rieger, 2000).

Deodoran merupakan salah satu sediaan kosmetik seperti lotion yang terdiri dari sebuah sistem emulsi minyak dalam air $(\mathrm{m} / \mathrm{a})$. Emulsi adalah dispersi atau suspensi suatu cairan dalam cairan lain yang tidak dapat bercampur dalam keadaan biasa karena molekul-molekul cairannya bersifat saling antagonistik yang disebabkan perbedaan sifat kepolarannya. Cairan yang terdispersi discbut fasa internal sedangkan cairan yang mendispersi (pendispersi) disebut fasa cksternal (Suryani et al., diacu dalam Inugraha).

Deodoran adalah sediaan
kosmetika yang digunakan untuk menyerap keringat dan mengurangi bau badan. Antiperspiran adalah sediaan kosmetika yang digunakan mempersempit pori sehingga mengurangi keluarnya keringat. Meningkatnya penggunaan antiperspiran dan deodoran disebabkan oleh pergaulan modern, sehingga dirasa perlu untuk mengurangi bau badan, yang disebabkan perubahan kimia keringat oleh bakteri (Bayyinah, 2011). Deodoran merupakan salah satu contoh bentuk sistem cmulsi minyak dalam air $(\mathrm{m} / \mathrm{a})$ seperti lotion yang memiliki kekentalan tertentu. Kekentalan dari deodoran ini dalam aplikasinya bertujuan agar deodoran yang dipakai tidak tumpah melalui bola (roll-on) pada bahan kemasannya.

Selama ini, yang mempengaruhi kckentalan dalam formulasi deodoran adalah ennilsifier. Eimulsifier merupakan senyawa yang mempunyai aktivitas permukaan (surface-active agents) schingga dapat menurunkan tegangan permukaan (surface tension) antara udaracairan dan cairan-cairan yang terdapat dalam suatu sistem. Penambahan pengental merupakan cara untuk meningkatkan kekentalan suatu sediaan, pengental yang digunakan yaitu Magnesium Aluminium Silikat (MAS).

MAS sangat berperan terhadap kekentalan, kemampuannya untuk terdispersi dengan air dan membentuk suatu struktur koloidal yang menghasilkan kekuatan untuk mensuspensi dan memiliki sifat mengentalkan. Konsentrasi MAS amat berpengaruh terhadap kekentalan sediaan deodoran. Berikut adalah struktur molekul MAS.
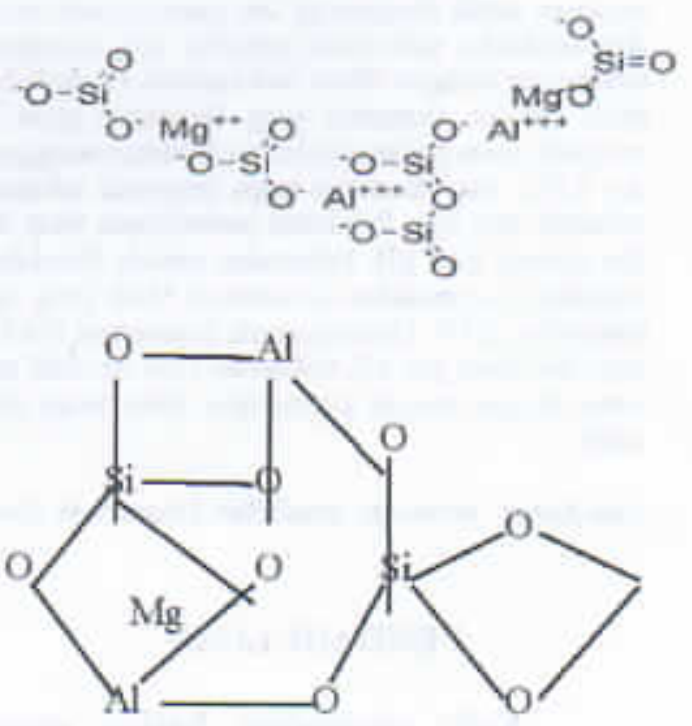

Gambar 1. Struktur Molekul Magnesium Aluminium Silikat 
Pada umumnya semakin tinggi konsentrasi pengental yang ditambahkan maka akan semakin tinggi kekentalan scdiaan, akan tetapi konsentrasi optimum yang menghasilkan viskositas sesuai standar mutu belum diketahui. Dalam emulsi kosmetik, MAS biasanya menghasilkan viskositas yang cukup besar. MAS dapat digunakan dengan konsentrasi antara $0,5 \%$ hingga $2 \%$ namun dapat menghasilkan viskositas dan kemampuan mensuspensi lebih besar, serta kestabilan emulsi yang lebih baik (Technical Data Veegum Ultra Magnesium Aluminium Silikat Part 1). Data lainnya menyebutkan bahwa konsentrasi MAS yang berfungsi sebagai stuspending agent $0,5-2,5 \%$ dan sebagai viscosity modifier adalah $2-10 \%$ (Wade. A, and P. J. Weller, 1994). Berdasarkan trial dan error yang telah dilakukan sebelumnya, maka konsentrasi yang digunakan adalah $0,5-2,0 \%$.

\section{Bahan dan Metode}

Bahan yang digunakan dalam penelitian ini, adalah air bebas ion (detonized water), pengemulsi (emulsifier), pelembut kulit (emollient), humcktan, zat aktif anti perspiran, zat aktif anti iritan, zat aktif anti bakteri, bahan aditif (parfum dan preservatif), dan pengental magnesium aluminium silikat. Peralatan yang digunakan, adalah Neraca analitik BL-320 H Shimadzu, piala gelas, kaca arloji, cawan porselen, spatula, mesin mixer homogenizer Tamaru, penangas listrik, labu semprot, termometer alkohol, $\mathrm{pH}$ meter (Pen Type), alat Sentrifuge Hettich Zentrifugen EBA 20, alat viscometer Brookfield RV DV-E VISCOMETER.

\section{Metode Penelitian}

Penelitian ini dilakukan secara eksperimental, dengan menggunakan empat konsentrasi yang berbeda $(0,5 \%$; $1,0 \% ; 1,5 \%$, dan $2 \%$ ) dengan tiga kali ulangan. Produk kontrol (tanpa pengentaI) dibuat berdasarkan formula deodoran yang ada di pasar.

$$
\text { berbagai konsentrasi Magnesium }
$$

Aluminium silikat (MAS) selanjutnya diuji kekentalan dan kestabilan emulsinya. Uji kekentalan dilakukan dengan metode Brookfield. Alat yang digunakan adalah Brookfield RV DV-E Viscometer. Uji kestabilan emulsi menggunakan Sentrifuge Hettich Zentrifugen EBA 20.

\section{Pembuatan Deodoran}

Pada bahan - bahan yang digunakan dalam pembuatan deodoran roll-on dipisahkan menjadi dua bagian yaitu bahan yang larut minyak (fase minyak atau sediaan 1) dan bahan yang larut air (fase air atau sediaan 2). Bahan bahan yang termasuk fase minyak pengermulsi (emulsifier) dan pelembut kulit (emollient), dimasukkan ke dalam gelas piala.

Pengental Magnesium Aluminium Silikat (MAS) yang digunakan, terlebih dahulu dilarutkan ke dalam air sebelum dicampur dengan fase air lainnya. Kemudian diaduk dengan homogenizer $3000 \mathrm{~mm}$ selama 10 menit. Setelah itu, dicampurkan dengan fase air lainnya.

Sediaan 1 dan 2 dipanaskan dan diaduk pada suhu $70-75^{\circ} \mathrm{C}$ secara terpisah hingga homogen. Sediaan yang telah homogen tersebut dicampur dan diaduk dengan pengaduk. Proses pencampuran kedua sediaan yang berbeda tersebut dilakukan pada suhu $70^{\circ} \mathrm{C}$. Proses pengadukan dengan Homogenizer 3000 rpm selama 10 menit, kemudian diaduk dengan pengaduk hingga campuran kedua sediaan homogen dan meneapai suhu $50^{\circ} \mathrm{C}$ (sediaan 3).

Bahan aktif seperti anti perspirant dan anti iritan, dimasukkan pada suhu $50^{\circ} \mathrm{C}$, kemudian diaduk dengan pengaduk hingga homogen. Proses pengadukan dilakukan hingga eampuran kedua sediaan homogen dan mencapai suhu $40^{\circ} \mathrm{C}$. Pengawet dan parfum dimasukkan $\mathrm{kc}$ dalam sediaan 3 pada suhu $40^{\circ} \mathrm{C}$ kemudian diaduk dengan pengaduk selama kurang lebih satu menit. 


\section{Pengujian Spesifikasi Mutu Deodoran}

Pengujian spesifikasi deodoran meliputi analisis pengukuran organoleptik, $\mathrm{pH}$ (derajat keasaman), kekentalan, stabilitas emulsi, total mikroba dan uji panel.

\section{A. Pengukuran Organoleptik (Standar Perusahaan)}

Parameter

pengukuran organoleptik berdasarkan pengamatan dilakukan terhadap bentuk, wama, dan aroma sediaan lotion sctclah proses pembuatan serta dibandingkan dengan standar perusahaan untuk sediaan lotion deodoran. Parameter ini dilakukan secara subyektifitas.

\section{B. Derajat Keasaman (pH) (SNI 16- 0218-1997)}

Sediaan lotion deodoran yang akan dicek $\mathrm{pH}$ nya disiapkan terlebih dahulu. Kemudian $\mathrm{pH}$ meter dikalibrasi dengan larutan buffer $\mathrm{pH} 4$ dan $\mathrm{pH} 7$ setiap kali akan melakukan pengukuran. Elektroda yang telah dibersihkam dengan aquades kemudian dicelupkan $\mathrm{ke}$ dalam sediaan yang diperiksa dengan membuat larutan sediaan lotion $5 \%$. Tunggu beberapa saat sampai nilai $\mathrm{pH}$ yang terukur tetap stabil atau konstan. Catat nilai $\mathrm{pH}$ yang terukur. Bandingkan pH yang dihasilkan oleh sediaan lotion deodoran dengan standar deodoran.

\section{Kekentalan (Brookfield Engineering Laboratories, Inc., 1986)}

Alat viscometer Brookfield disambungkan dengan arus listrik, tekan power pada stabilizer, cek gelembung udara agar berada ditengah lingkaran, dan tekan power dibclakang Brookfield. Kemudian disediakan sediaan dalam wadah yang telah disiapkan untuk pengecekan kekentalan. Siapkan spindle yang sesuai dan dimasukkan ke dalam penyangga spindle. Skrup yang ada dibagian kanan dinaik turunkan sampai permukaan bulk menutupi setengah (1/2) dari jeda yang ada pada spindle.

Tombol select ditekan ke kanan untuk menyesuaikan spindle. Kemudian tombol bulat diputar sampai angka pada kanan bawah display sesuai dengan angka pada spindle. Tombol select ditekan ke kiri untuk menyesuaikan speed. Kemudian tombol bulat diputar hingga angka pada kiri bawah display sesuai dengan speed yang diperlukan. Kembalikan tombol select ke tengah. Untuk melihat range yang bisa diukur dengan speed dan spmalle tersebut, ditekan autorange, kemudian dilihat display.

Untuk mengukur viskositas sediaan, ditekan motor on sampai dua kali putaran spindle. Bila telah selesai mengukur, ditekan kembali motor on, sampai terlihat off disebelah angka speed pada display. Dicatat hasilnya. Alat viscometer Brookfield dinaikkan. dilepaskan spindle ke arah berlawanan. Bersihkan sediaan yang tersisa pada spindle dan penyangga nya. Penyangga serta spindlenya dilap hingga bersih. Untuk mematikan alatnya, tekan tombol power yang terletak dibelakang Brookfield. Tekan power agak lama pada stabilizer sampai mati.

D. Stabilitas emulsi (Lachman)

Menggunakan Sentrifuge Hettich Zentrifugen EBA 20. Dimasukkan sampel ke dalam tabung sentrifuge sekitar $1 / 3$ bagian tabung. Dipanaskan sampai suhu $50^{\circ} \mathrm{C}$, kemudian dimasukkan ke dalam alat sentrifugasi.

Diset mesin sentrifugasi :

Kecepatan $\quad: 3000 \mathrm{rpm}$

Waktu $: 20$ menit

Setelah 20 menit, diamati hasil sentrifusnya, bila terjadi pemisahan fase maka dapat dikatakan cmulsi lotion tersebut tidak stabil. Bila tidak terjadi pemisahan fase, maka emulsi lotion tensebut stabil. 


\section{E. Uji Total Mikroba (Fardiaz, 1989)}

Pengukuran total mikroba berdasarkan (Peraturan Ka. BPOM No. HK. 03.1.23.07.11.6662 Tahun 2011 Tentang Persyaratan Cemaran Mikroba dalam Kosmetik). Secara aseptis ditimbang sediaan deodoran sebanyak 1 gram dan dimasukkan ke dalam larutan pengeneer (garam fisiologis) kemudian dihomogenkan. Pengenceran dilakukan sampai $10^{-1}$. Sebanyak $1 \mathrm{ml}$ dari sediaan deodoran diinokulasikan pada cawan petri steril. Media Tryptic Soy Agar (TSA) untuk ANGKA IEMPENG TOTAL (ALT) Bakteri, media Saboraud Dextrose Agar (SDA) untuk Angka Kapang Khamir, media Manitol Salt Agar (MSA) untuk Staphylococcus aureus, media Centrimide Agar (CA) untuk Pseudomonas aerugmosa. Media yang steril pada suhu $45-55^{\circ} \mathrm{C}$ dituangkan pada cawan petri scbanyak $10-15 \mathrm{~mL}$. Cawan petri digoyang dan dibiarkan memadat. Inkubasi dilakukan pada suhu $37{ }^{\circ} \mathrm{C}$ selama $18-24$ jam. Jumlah koloni yang tumbuh dilaporkan sebagai total mikroba.

\section{F. Lji Panel}

Uji pancl dilakukan terhadap produk yang meliputi homogenitas, kelembutan, kesan lengket dikulit, daya alir, dan penerimaan panelis terhadap produk. Panelis adalah karyawan PT Paragon Technology and Innovation sebanyak 30 orang wanita berusia 18 sampai 27 tahun.

\section{HASIL DAN PEMBAHASAN}

\section{A. Pengaruh Penambahan Magnesium Aluminium Silikat terhadap Bentuk, Warna, dan Bau dari pengujian organoleptik.}

Untuk parameter bentuk, semakin tinggi konsentrasi MAS bentuk sediaan deodoran semakin mengental dan viskosilasnya masuk $\mathrm{ke}$ dalam sedian cream sesuai dengan Tabel 1 . Hal ini sesuai dengan pernyataan Schmitt (1996) yaitu pada umumnya semakin tinggi konsentrasi pengental yang digunakan maka viskositas akan semakin tinggi. Semakin tinggi viskositas suatu bahan, maka bahan tersebut akan semakin stabil karena pergerakan partikel cenderung sulit dengan semakin kentalnya suatu bahan.

Untuk parameter wama, semakin tinggi konsentrasi MAS yang ditambahkan menyebabkan sediaan deodoran berwama sedikit kusam, tetapi pada konsentrasi rendah tidak terialu mempengaruhi warna deodoran. Hal ini sesuai pernyataan Mitsui (1997) bahwa warna yang terbentuk pada produk dipengaruhi oleh wama bahan bahan penyusunnya. Berdasarkan hasil pengujian organoleptik, semua sediaan baunya sesuai standar.

\section{B. Pengaruh Penambahan Magnesium Aluminium Silikat terhadap Nilai $\mathrm{pH}$}

Penambahan pengental MAS tidak memberikan pengaruh yang signifikan terhadap $\mathrm{pH}$ deodoran dan masih sesuai dengan spesifikasi milik perusahaan $(3,5$ $5,0)$. Nilai $\mathrm{pH}$ yang diperoleh berdasarkan hasil penelitian rata - rata berkisar antara $4,60-5,01$ seperti yang terlihat pada gambar 1.

Hasil pengujian nilai $\mathrm{pH}$ yang bersifat asam discbabkan karena pH MAS yang asam yaitu 4,7. Selain itu juga disebabkan karena dalam formulasi deodoran menggunakan bahan aktif aluminium klorohidrat $17,5 \%$ yang berfungsi mengurangi keluarnya keringat (antiperspiran) dan menghilangkan bau keringat (deodoran). Menurut Williams dan Schmitt (1996), untuk larutan aluminium klorohidrat $15 \%$ memiliki $\mathrm{pH}$ 4,3 .

\section{Pengaruh Penambahan Magnesium Aluminium Silikat (MAS) terhadap Kekentalan}

Penambahan pengental MAS dalam deodoran dapat meningkatkan kekentalan. Hal ini didukung oleh pernyataan yang menyatakan bahwa MAS berfungsi sebagai adsorben, zat penstabil, serta zat untuk meningkatkan viskositas 
(Handbook of Pharmaceutical Exicipients. hlm 269) seperti yang terlihat pada gambar 2.

Pada penambahan konsentrasi MAS $0,5 \%$ menghasilkan sediaan deodoran dengan rata - rata viskositas 1294 ep yang memenuhi kisaran standar milik perusahaan yang bernilai $900-2000$ cp. Untuk sediaan dengan penambahan konsentrasi MAS 1,0\% menghasilkan viskositas yang melebihi standar perusahaan (terlalu kental) dengan rata rata $2116 \mathrm{cp}$. Uji kekentalan dilakukan dengan metode Brookfield. Alat yang digunakan adalah Brookfield RV DV-E Viscometer. Prinsip kerja viskometer Brookfield ini adalah semakin kuat putaran semakin tinggi viskositasnya sehingga hambatannya semakin besar.

\section{Pengaruh Penambahan Magnesium Aluminium Silikat terhadap Stabilitas Emulsi}

Untuk memperoleh nilai kestabilan suatu sediaan farmasetika atau kosmetik dalam waktu singkat maka dapat dilakukan uji stabilitas dipercepat. Pengujian ini dimaksudkan untuk mendapatkan informasi yang diinginkan pada waktu sesingkat mungkin dengan cara menyimpan sampel pada kondisi yang dirancang untuk mempereepat terjadinya perubahan yang biasanya terjadi pada kondisi normal.

Pengujian diperecpat yang dilakukan kali ini yaitu uji mckanik (centrifugal test). Tujuan dilakukan uji mekanik/centrifugal test adalah untuk mengetahui terjadinya pemisahan fase dari emulsi. Data Hasil Pengujian Stabilitas Emulsi dengan Sentrifuga menunjukkan bahwa deodoran tanpa penggunaan MAS dan dengan penggunaan konsentrasi $0,5 \%$; $1,0 \%$ dan $1,5 \%$ menghasilkan stabilitas emulsi tidak stabil, sedangkan dengan penggunaan MAS $2,0 \%$ hasil stabilitas cmulsinya stabil.

Tabel 1. Hasil Pengujian Organoleptik, Bentuk, Wama, Bau.

\begin{tabular}{llll}
\hline MAS, \% & Bentuk & Warna & Bau \\
\hline 0 & Lotion & Putih susu & Standar \\
0,5 & Lotion & Putih susu & Standar \\
1,0 & Lotion & Putih susu & Standar \\
1,5 & Cream & Putih kelabu & Standar \\
2,0 & Cream & Putih kelabu & Standar \\
\hline
\end{tabular}

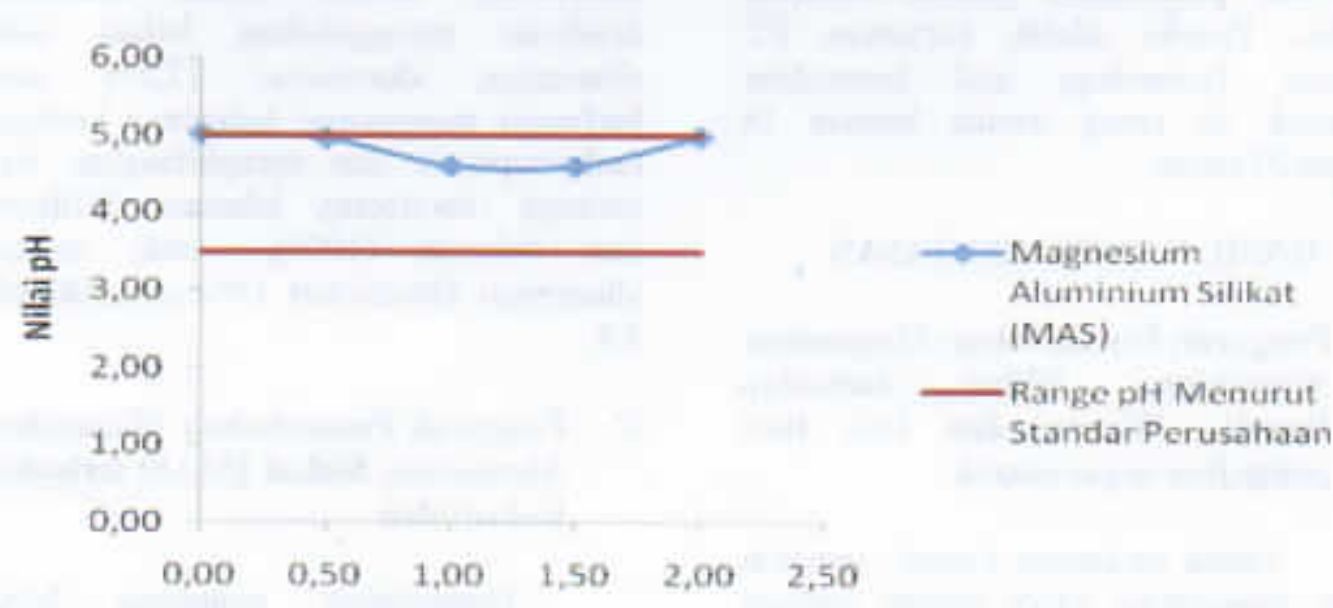

Konsentrasi Magnesium Aluminium Silikat (\%)

Gambar 1. Grafik Hubungan antara Konsentrasi Magnesium Aluminium Silikat (MAS) dengan $\mathrm{pH}$ 


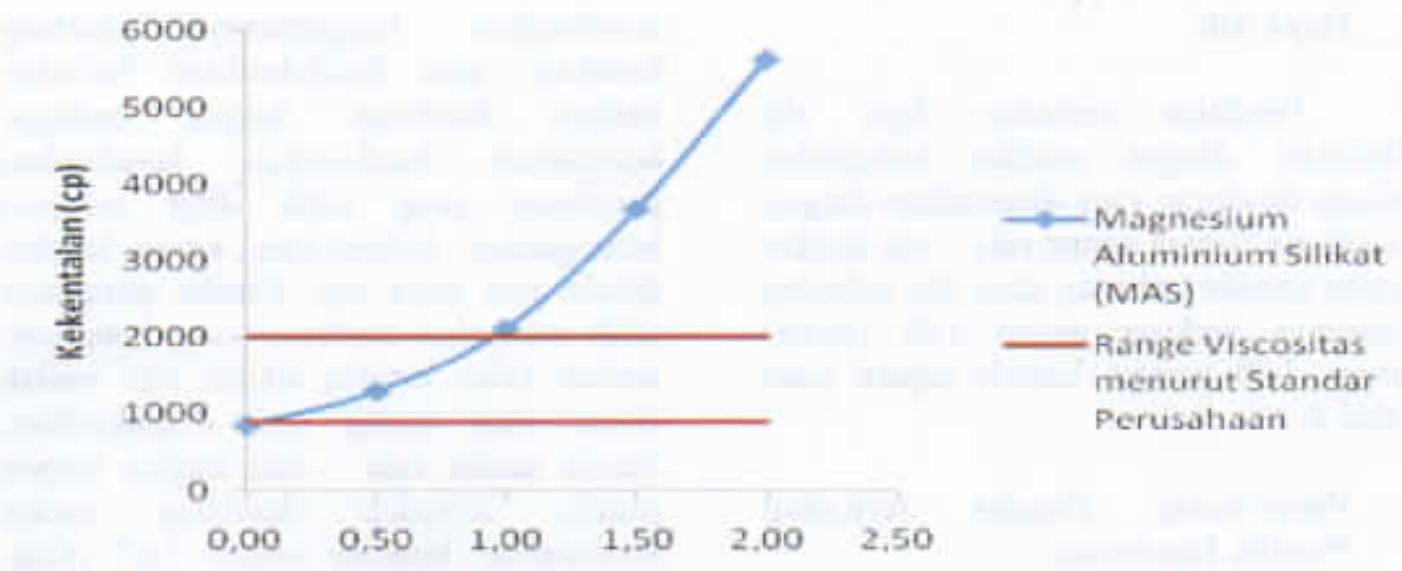

Konsentrasi Magnesium Aluminium Silikat (\%)

Gambar 2 Grafik Hubungan antara Konsentrasi Magnesium Aluminium Silikat (MAS) dengan Kekentalan

\section{E. Pengaruh Penambahan Magnesium Aluminium Silikat (MAS) terhadap Total Mikroba}

Analisis Total Mikroba amat penting dilakukan karena hal ini berkaitan dengan umur pakai produk dan keamanan bagi media pengaplikasian produk tersebut. Jika produk deodoran memiliki total mikroba di atas standar yang telah ditctapkan maka produk tersebut tidak akan berfungsi menecgah atau menghilangkan bau keringat tetapi sebaliknya akan menimbulkan bau yang tidak sedap bahkan mungkin menyebabkan iritasi pada kulit. Total mikroba pada deodoran dengan penambahan MAS dan kontrol dengan pengenceran sampai $10^{-1}$ dengan pengamatan yang dilakukan selama 24 jam diperoleh hasil negatif. Hasil ini memenuhi standar perusahaan yaitu batas total mikroba yang diperbolehkan pada produk sebesar $<1000 \mathrm{efu} / \mathrm{g}$. Angka Kapang dan Khamir dilakukan dengan pengenceran sampai $10^{-2}$ dengan pengamatan yang dilakukan selama 3 hari diperoleh hasil negatif.

Pengawet yang digunakan dalam formulasi deodoran terbukti efcktif mencegah tumbuhnya mikroba yang dapat merusak deodoran. Pengawet yang digunakan dalam formulasi adalah metil paraben. Menurut Grossman (1997), konsentrasi optimum metil paraben yang digunakan adalah $0,25 \%$.

\section{F. Uji Panel}

\section{Homogenitas}

Semakin tinggi homogenitasnya maka semakin stabil produk tersebut. Penilaian homogenitas dilakukan dengan cara mengamati penampakan visual deodoran. Secara umum rata - rata tingkat respon panelis terhadap homogenitas berkisar antara 3,43 (biasa) hingga 4,27 (suka) seperti dalam Tabel 1.

\section{Kelembutan}

Penilaian terhadap kelembutan dilakukan pada waktu sediaan deodoran dioleskan pada kulit. Secara umum ratarata tingkat respon panelis terhadap kelembutan berkisar antara 3,27 (biasa) hingga 4,27 (suka) seperti dalam Tabel 2.

\section{Kesan Lengket di Kulit}

Penilaian terhadap kesan lengket dikulit dilakukan setelah beberapa saat sediaan deodoran dioleskan pada kulit. Secara umum rata - rata tingkat respon panelis terhadap kesan lengket dikulit berkisar antara 2,50 (tidak suka) hingga 3,50 (biasa) seperti dalam Tabel 3. 


\section{Daya Alir}

Penilaian terhadap daya alir dilakukan dengan melihat kekentalan sediaan deodoran yang disesuaikan dengan wadahnya. Secara umum rata - rata tingkat respon panelis terhadap daya alir terhadap wadahnya berkisar antara 1,93 (encer) hingga 4,90 (sangat kental) seperti pada Tabel 4.

\section{Penerimaan Panelis terhadap Produk Deodoran}

Pada Tabel 5 menunjukkan uji penerimaan, panelis diminta untuk memberikan tanggapannya tentang kesukaan atau ketidaksukaan terhadap sediaan deodoran dengan berbagai konsentrasi berdasarkan keseluruhan parameter yang telah diuji meliputi homogenitas, kelembutan, kesan lengket dikulit dan daya alir. Panelis umumnya lebih menyukai deodoran yang homogen, lembut, tidak lengket dikulit, dan mudah keluar dari wadah saat diaplikasikan. Secara umum rata - rata tingkat respon panelis terhadap deodoran secara keseluruhan berkisar antara 1,67 (tidak suka) hingga 3,93 (suka).

Tabel 1. Nilai Rata - rata Homogenitas Deodoran oleh Panelis

\begin{tabular}{cc}
\hline Konsentrasi MAS $(\%)$ & Nilai rata - rata homogenitas \\
\hline 0,0 & 4,27 \\
0,5 & 3,70 \\
1,0 & 3,73 \\
1,5 & 3,70 \\
2,0 & 3,43 \\
\hline
\end{tabular}

Keterangan Skala Kesukaan terhadap Homogenitas :

$5=$ Sangat suka

$4=$ Suka

$3=$ Biasa

2 = Tidak suka

$1=$ Sangat tidak suka

Tabel 2. Nilai Rata - rata Kelembutan Deodoran oleh Panelis

\begin{tabular}{cc}
\hline Konsentrasi MAS $(\%)$ & Nilai rata - rata kelembutan \\
\hline 0,0 & 4,27 \\
0,5 & 3,67 \\
1,0 & 3,67 \\
1,5 & 3,67 \\
2,0 & 3,27 \\
\hline
\end{tabular}

Keterangan Skala Kesukaan terhadap Kelembutan :

$5=$ Sangat suka

$4=$ Suka

$3=$ Biasa

$2=$ Tidak suka

1 = Sangat tidak suka 
Tabel 3. Nilai Rata - rata Kesan Lengket Deodoran oleh Panelis

\begin{tabular}{cc}
\hline Konsentrasi MAS (\%) & Nilai rata -rata kesan lengket \\
\hline 0.0 & 3,50 \\
0,5 & 2,87 \\
1,0 & 2,50 \\
1,5 & 2,70 \\
2,0 & 3,23 \\
\hline
\end{tabular}

Keterangan Skala Kesukaan terhadap Kesan Lengket :

$5=$ Sangat suka

$4=$ Suka

$3=$ Biasa

$2=$ Tidak suka

$1=$ Sangat tidak suka

Tabel 4. Nilai Rata - rata Daya Alir Deodoran oleh Panelis

\begin{tabular}{cc}
\hline Konsentrasi MAS $(\%)$ & Nilai Rata - rata daya alir \\
\hline 0,0 & 1,93 \\
0,5 & 1,97 \\
1,0 & 3,00 \\
1,5 & 3,83 \\
2,0 & 4,90 \\
\hline
\end{tabular}

Keterangan Skala Penilaian Daya Alir Deodoran terhadap Wadah :

$5=$ Sangat kental

$4=$ Kental

$3=$ Agak kental

$2=$ Encer

$1=$ Sangat encer

Tabel 5. Nilai Rata - rata Penerimaan Deodoran oleh Panelis

\begin{tabular}{cc}
\hline Konsentrasi MAS (\%) & $\begin{array}{c}\text { Nilai rata - rata } \\
\text { penerimaan deodoran }\end{array}$ \\
\hline 0,0 & 3,93 \\
0,5 & 3,57 \\
1,0 & 2,80 \\
1,5 & 2,27 \\
2,0 & 1,67 \\
\hline
\end{tabular}

Keterangan Skala Penerimaan Deodoran :

$5=$ Sangat suka

$4=$ Suka

$3=$ Biasa

$2=$ Tidak suka

$1=$ Sangat tidak suka 


\section{KESIMPULAN}

Berdasarkan hasil penclitian yang diperoleh, dapat disimpulkan bahwa konsentrasi Magnesium Aluminium Silikat (MAS) yang optimal sebagai pengental dalam pembuatan deodorant roll-on adalah konsentrasi $0,5 \%$. Deodorant roll-on dengan konsentrasi MAS $0,5 \%$ mempunyai karakteristik pH 4,9, viskositas $1294 \mathrm{cP}$; total miluroba menunjukan hasil yang negatif, ketiga parameter ini sesuai dengan standar perusahaan. Akan tetapi pada konsentrasi MAS $0,5 \%$ menghasilkan stabilitas emulsi yang tidak stabil.

\section{DAFTAR PUSTAKA}

Anita, S. B. 2008. Aplikasi Karaginan dalam Pembuatan Skin Lotion. IPB. Bogor.

Brookfield Engineering Laboratories, Ine. 1986. More Solution To Sticky Problems. Edisi Revisi. Massachussetts,USA.

Departemen Kesehatan Republik Indonesia. 1995. Farmakope Indonesia edist $I V$. Badan Pengawas Obat dan Makanan, Jakarta.

Djajadisastra, 2003. Cosmetic Stability: Departemen Farmasi FMIPA UI. Seminar HIKI 2003.

Goldschmidth Personal Care. 2000. Catalog of Product. Germany.

Inugraha. 2003. Aplikasi Gelatin Tipe A dari Kulit Sapi sebagai Bahan Pengental (thickening agent) dalam Formulasi Deodorant Roll On. Skripsi. IPB Bogor.

Kramcr, D. 1996. The Viscosity Detemination of Waste-Glass For Characteristization of Verification Process. New York.
Lee, K. P., R.C. Mason, and T, Ree, 1972. The Flocculattion of Veegum Suspension by Electrolytes. Journal of the Korean Chemical Society. Volume 16, No.1. Republic of Korea. Korea.

Lewis, RJ. 1987. Howless Condenced Chemical Dictionary $1 l^{\text {mi }}$ ed. Van Nostrand Reinhold Company Ine. New York.

Mitsui, T. 1997. New Cosmetic Science. Elsevier, science B.V. The Netherlands. Amsterdam.

Nugraha, L. S. A. 2012. Pengaruh Kadar CMC Na Sebagai Bahan Pengental Terhadap Sifat Fisik Lotion Repelan Minyak Atsin Akar Wangi (Vetivera zizanioides (L) Nogh), Laporan Proposal Karya Tulis limiah. Akademi Farmasi Teresiana. Semarang

Panitia Kodeks Kosmetika Indonesia. 1980. Kodeks Kosmetika Indonesia. Volume I. Departemen Kesehatan Republik Indonesia. Jakarti.

Panitia Badan Pengawas Obat dan Makanan. 2011. Peraturan Ka.BPOM No. HK. 03.1.23.07.11.6662 Tentang Persyaratan Cemaran Mikroba dalam Kasmetik. Badan Pengawas Obat dan Makanan. Jakarta.

Panitia Badan Pengawas Obat dan Makanan. 2003. Peraturan Ka. BPOM No. HK 00.05,4.1745. Tentang Kosmetik. Badan Pengawas Obat dan Makanan. Jakarta.

R.T. Vanderbilt company. Tanpa Tahun. Technical Data Veegum Ultra Magnesium Aluminium Silikat Part I. Norwalk. USA. 
R. T. Vanderbilt company. Tanpa Tahun. Technical Data Veegum Ultra Magnesium Aluminiom Silikat Part 3. Norwalk. USA.

Rieger, M. M. 1994. Harry's cosmeticology get edition. Chemical Publishing, co, Inc. New York.

Schrader K. and A. Domsch. 2005. Casmetology-Theory and Practice Research. Test Methods. Analysis. Formulas. Volume $\mathrm{L}$ Kressler Druck + Medien, Bobingen. Germany.

Suryani A, I. Sailah, E. Hambali. 2000. Teknologi Emulsi. Jurusan Teknologi
Industri Pertanian, Fakultas Teknologi Pertanian, IPB. Bogor.

Tim Penyusun Farmakope Indonesia. 1995. Farmakope Indonesia. Edisi ke-4. Departemen Keschatan Republik Indonesia. Jakarta.

Usman, H.\& R. Purnomo Setiady Akbar.2000. Pengantar Statistika. Buni Aksara. Jakarta.

Wade, A. and P. J. Weller. 1994. Handbook of Phamacentical Excipients $2^{\text {nt }}$ edition. The Pharmaceutical Press London. England. 